DOI https://doi.org/10.18551/rjoas.2018-06.19

\title{
BUSINESS STRATEGY ANALYSIS: AFTER SCHOOL PROGRAM AND DAYCARE OF «BUNNIES»
}

\author{
Kartono Wati Sulasmini* \\ Post-graduate Program of Faculty of Economics and Business, University of Esa Unggul, \\ Indonesia
}

Syah Tantri Yanuar Rahmat, Pusaka Samerdanta, Darmansah, Lecturers

Faculty of Economics and Business, University of Esa Unggul, Indonesia

*E-mail: stonekripsoprast2012@gmail.com

ORCID: 0000-0003-4345-5219

\begin{abstract}
Daycare and after-school program is highly needed by parents because it is an alternative for parents who do not have the time to educate, nurture children and the needs of parents who want to socialize outside their working hours. The business of daycare and after-school programs that have been running have not fully utilized the technological system in accordance with the ages. Many of them still use conventional methods. Therefore, daycare and after school programs must have innovative new breakthrough in providing facilities for consumers. The business strategies discussed by the researcher include: business environment analysis, business strategy, canvas business model, human resource strategy, operational strategy, site selection and layout strategy, marketing strategy.
\end{abstract}

\section{KEY WORDS}

Business strategy, after school program, daycare, educational system.

Along with the development and progress of the era where housewife plays an important role in supporting family economy, therefore many parents, especially housewives do not have time to guide, nurture, and educate their children at home. Because of this business, the parents need a daycare and a place to learn for their child. In addition, many parents concern about how to explore the changing intellectual development of children who do not fit their way of educating children in their time.

Many daycare centers that run today do not provide satisfaction to parents in supporting the growth and the development of intellectual and childhood personalities. The needs of daycare and after-school programs are still needed in South Tangerang area. The needs of the after school and daycare programs are very much sought after by busy parents working, so they can be calm in doing their work and not worry about supervision and guidance as well as the intellectual and childcare management during their busy work, (Geoffroy et al., 2006).

Daycare and after-school programs are needed by parents because it is an alternative for parents who do not have the time to educate, nurture children and the needs of parents who want to socialize outside their working hours. From some of the problems found in this field, the business opportunity to open a daycare business and after school program still provides promising opportunities and potentials (Mahoney et al., 2005).

The business of daycare and after-school programs that have been running have not fully utilized the technological system in accordance with the ages. Many of them still use conventional methods. For that reason, daycare and after school programs must have innovative new breakthroughs in providing facilities for consumers. These new breakthroughs are downloadable applications in gadgets or other technological devices like ipad, computers, and so forth.

The need for the internet today is an inevitable need such as online streaming, where parents who entrust their children can access to monitor child development and their 
children's activities during their busy work which can be anytime and anywhere to access children's activities those who are entrusted, educated and cared for in day care and afterschool programs. The advantages of daycare and after-school programs are helping to dig up the child's talent in accordance with the hope and the growth of the child with activities that trigger the child's interest.

\section{RESULTS AND DISCUSSION}

Business Environment Analysis. Analysis of industry competition for these daycare and after- care programs uses a porter five' forces which results in the high threat of new arrivals, low competitor threats in the same field, low substitution threats, low consumer bargaining power, and low supplier bargaining power (Grundy, 2006). Seeing from this porter analysis, the business opportunity of daycare and after school program is still promising besides the opportunity and threat analysis where the daycare business and after school program that will be in Summarecon Gading-Serpong area which is the area of offices, apartment and residence does not have place of childcare and after-school programs which are qualified and complete.

Table 1 - Business Opportunities and Threats

\begin{tabular}{|l|}
\hline OPPORTUNITY \\
\hline There is no International standard \\
\hline It has small amount in the area and far apart \\
\hline Franchise opportunities in the future and formal school from playgroup until high school \\
\hline The number of female workers is quite a lot \\
\hline Parents who are busy working and no time to nurture and educate can see the child's growth and development \\
\hline THREAT \\
\hline The number of educators and caregivers are less skilled and professional than suppliers \\
\hline The economic crisis of a country \\
\hline Issue in other places that are less good such as child abuse, children kidnapping, and others \\
\hline Easy government permission to open the daycare business and after school programs \\
\hline Prices compete in the same field \\
\hline
\end{tabular}

Table 2 - Business Strengths and Weaknesses

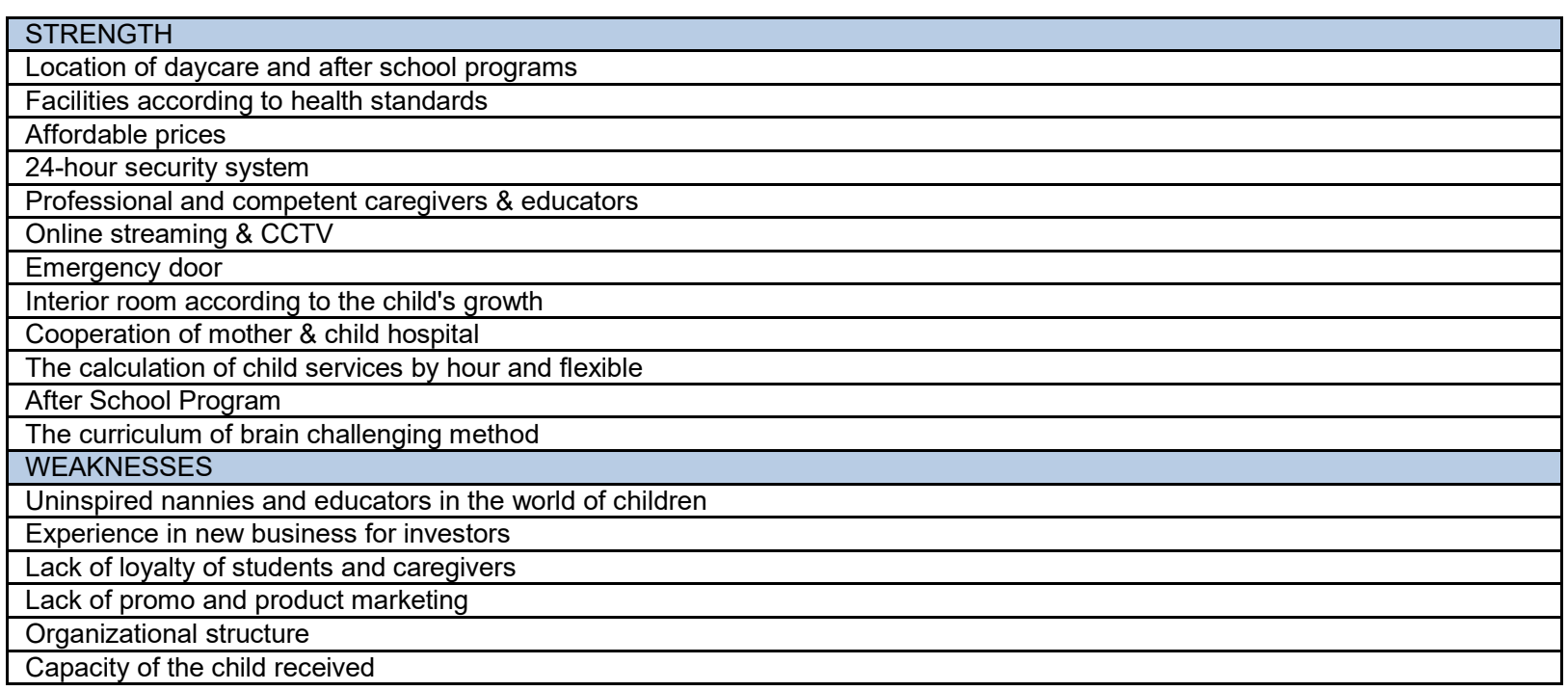

The daycare centers in the community are far enough away from each other and many international schools do not have after-school programs that satisfy parents for their children. There are several daycare and after-school programs in this area of South Tangerang city; it is a necessary strategy in facing price competition while improving quality both in terms of educator, caregiver, and program offered as well as good management in managing business daycare and after school program. If this price competition can be controlled by maintaining quality, providing good service, strategy in marketing service products and 
having different methods of educating and nurturing existing children so far, competitive prices are no longer a threat in business.

Business strategy. Childcare and after school programs of Bunnies provide childcare, education and care services starting from the age of 0 months to 12 years old located at Summarecon Serpong location in Gading Serpong South Tangerang, Banten. This business is to keep children whose parents are busy working and have little opportunity and time to care for, nurture, and educate their children but they can still monitor their child's growth.

To determine the feasibility of whether this business can provide opportunities and potential good and profitable, then it is evaluated by using matrices based on opportunity, threat, weakness and strength, ( Porter, 2008).

EFE Matrix; daycare and after school programs of Bunnies business are in good shape, taking advantage of the opportunities that exist outside and avoiding the threat of competition faced by Bunnies company. IFE Matrix; the average position indicates that this business needs improvement in operational business, strategy, and other procedures. CPM matrix; after-school and daycare program of Bunnies business has 24-hour security, spacious and free parking, online streaming and CCTV, extensive and complete playground, 1: 5 child rearing ratio, interest and talent curriculum, operation hours, supervised by experts, pleasant surroundings, emergency doors, anti-bacterial ventilation systems, fungi and allergies, and the presence of after-school programs are factors of critical after-school and day care of Bunnies business success.

Table 3 - Analysis of Canvas Business Model

\begin{tabular}{|c|c|c|c|c|}
\hline Key Partners & Key Activities & $\begin{array}{c}\text { Value } \\
\text { Propositions }\end{array}$ & Customer Relationship & Customer Segments \\
\hline \multirow[t]{3}{*}{$\begin{array}{l}\text { Strategy of } \\
\text { cooperation with } \\
\text { provider of baby } \\
\text { sitter, hospital and } \\
\text { pediatrician }\end{array}$} & $\begin{array}{l}\text { Providing professional } \\
\text { caregiver, and child } \\
\text { educator according to } \\
\text { the needs of international } \\
\text { standard consumers }\end{array}$ & $\begin{array}{l}\text { Online streaming } \\
\text { and Bunnies } \\
\text { apps } \\
\text { Brain } \\
\text { Challenging } \\
\text { Method } \\
\text { Educators and } \\
\text { caregivers are } \\
\text { competent } \\
\text { Ratio1: } 5 \\
\text { caregivers and } \\
1: 10 \text { educators }\end{array}$ & $\begin{array}{l}\text { The relationship between } \\
\text { daycare and after school } \\
\text { programs with customers in } \\
\text { the long term until the child } \\
\text { takes the necessary advanced } \\
\text { education }\end{array}$ & $\begin{array}{l}\text { Parents of upper and } \\
\text { upper classes who } \\
\text { have children } \\
\text { between } 0-12 \text { years } \\
\text { old are busy working }\end{array}$ \\
\hline & Key Resources & & Channels & \\
\hline & $\begin{array}{l}\text { Physical assets: } \\
\text { business facilities, } \\
\text { operational vehicles, etc. } \\
\text { Human: caregiver \& } \\
\text { educator, customer } \\
\text { service, cleaning service } \\
\text { Financial: funds from } \\
\text { investors } \\
\text { Intellectual: brand, } \\
\text { customer database \& } \\
\text { partnerships }\end{array}$ & & $\begin{array}{l}\text { Advertised through electronic } \\
\text { media such as internet, } \\
\text { seminars, info session \& social } \\
\text { media. } \\
\text { Doing an event around the } \\
\text { daycare business \& after } \\
\text { school programs } \\
\text { Installing banners and } \\
\text { billboard }\end{array}$ & \\
\hline Cost Structure & & $\begin{array}{l}\text { Revenue } \\
\text { Streams }\end{array}$ & & \\
\hline \multicolumn{2}{|c|}{$\begin{array}{l}\text { Cost of caregiver \& educator } \\
\text { Cost of business location } \\
\text { Cost of interior and exterior business design } \\
\text { Operational costs such as electricity, water etc. } \\
\text { Other staff costs (security, administration, etc.) } \\
\text { Cost of Advertise and event } \\
\text { Cost of Childcare (milk, pampers, etc.) }\end{array}$} & \multicolumn{3}{|c|}{$\begin{array}{l}\text { Money received from children is deposited in daycare and after school } \\
\text { programs from parents of children. }\end{array}$} \\
\hline
\end{tabular}

SWOT Matrix; based on the matrix and SWOT analysis, it is found that there are two strategies performed by Bunnies according to SO and ST strategies in running the business that is customer intimacy (SO strategy) by approaching prospects and customers in selling products or services offered and knowing the knowledge of the customer to the product or service offered in accordance with the existing market which in this case break through the existing market (market penetration). The second strategy of daycare and after school 
programs of Bunnies is to perform excellent operations (ST strategies) that provide internal security and convenience such as online streaming and CCTV cameras as the example in excellent operational.

Great Strategy Matrix; daycare and after school programs of Bunnies located in quadrant 1 of its market strategy is market penetration which means the company is able to take advantage of external opportunities so that it can compete using aggressive business strategy. The strategy undertaken by Bunnies company is to conduct a product/service approach that is on offer with knowledge of prospective customers of products/services offered.

QSPM matrix; there are two alternative strategies that are excellent operational and customer intimacy to be considered by daycare business and after school programs of Bunnies. Daycare business and after school programs of Bunnies need a customer intimacy strategy that matches the analysis of SO strategy opportunities.

Human Resource Strategy. Bunnies company conduct their business in an organized, effective and efficient way in order to achieve organizational goals in providing care services and education of children optimally in order to create customer satisfaction and loyalty. Therefore, the concept of Bunnies company must have competent, professional and sensible human resources by following the rules set by the outlines of the education and culture department, the health and child social protection department. Bunnies will implement its HR activities using SMART (Specific, Measurable, Attainable, Result-oriented, and Time-bound) to achieve effective organizational goals which are stated specifically, measurable, achievable, result-oriented and within a certain time limit (DuFour, 2004).

Table 4 - Smart Short Term Human Resources

\begin{tabular}{|l|l|l|l|l|l|}
\hline No. & S & M & A & R \\
\hline 1 & $\begin{array}{l}\text { Recruiting professional and } \\
\text { skilled caregivers and educators }\end{array}$ & $100 \%$ & $\begin{array}{l}\text { Evaluating the service of } \\
\text { education personnel and nanny } \\
\text { every 3 months }\end{array}$ & $\begin{array}{l}\text { Cooperating with female labor } \\
\text { supplier }\end{array}$ & $\begin{array}{l}\text { First } \\
\text { year }\end{array}$ \\
\hline 2 & $\begin{array}{l}\text { Providing rewards and } \\
\text { employee punishment and } \\
\text { reducing turnover }\end{array}$ & $5 \%$ & $\begin{array}{l}\text { Gathering events together once } \\
\text { a year }\end{array}$ & $\begin{array}{l}\text { Increasing employee } \\
\text { engagement in all plans and } \\
\text { strategies }\end{array}$ \\
\hline
\end{tabular}

Table 5 - Smart Medium Term Human Resources

\begin{tabular}{|c|c|c|c|c|c|}
\hline No. & $\mathrm{S}$ & M & A & R. & $\mathrm{T}$ \\
\hline 1 & $\begin{array}{l}\text { Providing ongoing training and education } \\
\text { to become a model for other daycare } \\
\text { centers in delivering quality and } \\
\text { sustainable services }\end{array}$ & $100 \%$ & $\begin{array}{l}\text { Continuing education } \\
\text { and training twice a } \\
\text { year }\end{array}$ & $\begin{array}{l}\text { Conducting training and } \\
\text { education to caregivers and } \\
\text { child educators }\end{array}$ & $\begin{array}{l}\text { Sixth } \\
\text { Year }\end{array}$ \\
\hline 2 & Decreasing the turn over of employees & $3 \%$ & $\begin{array}{l}\text { Events abroad once a } \\
\text { year for outstanding } \\
\text { employees }\end{array}$ & $\begin{array}{l}\text { Increasing employee } \\
\text { engagement in all plans } \\
\text { and strategies }\end{array}$ & $\begin{array}{l}\text { Sixth } \\
\text { Year }\end{array}$ \\
\hline
\end{tabular}

Table 6 - Smart Long Term Human Resources

\begin{tabular}{|l|l|l|l|l|l|}
\hline No. & S & M & A & R \\
\hline 1 & $\begin{array}{l}\text { Reducing } \\
\text { employee turnover }\end{array}$ & $1 \%$ & $\begin{array}{l}\text { Cooperating, coordinating and developing } \\
\text { cooperation with other responsible } \\
\text { branches. }\end{array}$ & $\begin{array}{l}\text { Increasing employee } \\
\text { engagement in all plans and } \\
\text { strategies }\end{array}$ & $\begin{array}{l}\text { Tenth } \\
\text { Year }\end{array}$ \\
\hline
\end{tabular}

Targets of Bunnies human resources management consist of:

- Company Target is to provide a competent, certified, and sustainable workforce and provide continuous training and education in order to provide opportunities to improve self-actualization and protection to every employee in order to provide childcare and education services productively, effectively, and optimally.

- Functional Target is to provide and give services in accordance with the goals and targets to be achieved both in technical and non-technical aspect so that business activities can run functionally such as applications and online streaming.

- Social Target is to maintain business operations in accordance with ethical and social ways in the various needs and demands of the community by continuously minimizing 
the negative impacts arising from the demands faced in the business of daycare and after school program. Social target that will be achieved by daycare and after school programs of Bunnies is in the form of the fulfillment of lawsuits, profit companies and management relationships with trade union organizations, corporate relationships with surrounding communities, and CSR (discounts to communities around Bunnies).

- Employee Personal Target namely Bunnies will oversee and pay attention on the achievement of their respective goals that do not neglect their priorities on company goals.

PT. Bunnies Cinta Kasih uses lean management system and PDCA service in running its business operations aiming at reducing and avoiding excessive or unnecessary things like information about daycare and after school programs of Bunnies which can be done through online, parents who wish to enroll their children can do online registration through Bunnies websites or apps via smartphone and so on. In this case, Bunnies will use the PDCA service (Plan, Do, Check and Adjust) Plan service means parents who want to enroll their children in Bunnies company either after-school or daycare programs will be assisted in their planning to take what programs are needed for their child (Smith and Brown, 2012). Do service means that Bunnies will perform child care services and after school programs as optimal as possible so that parents who have registered their children get satisfaction. Check service means every child placed in daycare and after school programs of Bunnies will always be monitored for every development and activity and parents can also directly check their child's activities through coming to daycare and after school programs with the permission of the person responsible for managing the operations of Bunnies company or the parents can check their child's activities through streaming online by downloading daycare apps and after school programs of Bunnies. Adjust service means that if children who are enrolled by their parents as in after school programs do not like the program they choose because they change interest in other programs, then the children can move to the program they like even though the children are already present in the program that are not so interested.

Bunnies business runs by using situational leadership style. Leaders determine the obligations and responsibilities of individuals and groups, (Rustandi, 2007). Such behavior includes telling people what to do, how to do it, when to do it, where to do it, and who should do it, (Brahmasari dab Siregar, 2009). Leaders need to provide tasks, obligations, and responsibilities to his followers or his subordinates or to the extent to which the leader determines two-way or multidirectional communication, which includes listening, facilitating and supporting behavior, (Hersey et al., 2007).

In the early stages of this business, the role of active leaders influences employee behavior, but does not limit the employee's role in accomplishing tasks and responsibilities and helping to provide input to the solution of problems encountered (Schermerhorn et al., 2000). In changing the employee's behavior, the company will provide training and coaching that suit the needs of each of its employees. The role of Bunnies leadership style is that employees can comfortably work well and optimally resulting in productivity, effectiveness and efficiency of the performance of each employee. With the convenience of work and satisfaction of the performance of each employee, it will reduce employee turnover and resistance which all creates company loyalty and sense of belonging feeling.

Operational Strategy. The operational strategy of childcare and education is an integral part of supporting daycare services and after-school programs. Operations include the type, completeness, and quality of facilities used in carrying out the daycare and after school educational and childcare programs. Operational management is the activity of childcare and daycare management units on daycare and after school programs related to the planning, implementation, and supervision of the organization of the daycare and the after-school program. Operational financing of these activities includes the types and sources of financing required to organize and to develop childcare and education in daycare and after school program.

In order for the service of daycare and after school program to be well implemented, it is necessary that operational strategy for customers to feel comfortable and secure in the daycare activities as well as on the management of care and education to meet the needs of 
children .In addition, the financing that is managed by this business company must be done transparently so that it looks better in the process of cost for investment, operational and responsibility to other costs. With the presence of these components, daycare and after school services can be well implemented; an operational strategy is needed to ensure the continuity of business activities in accordance with the company's targets and objectives.

Location selection and layout strategy. Bunnies using LFR (Location Factor Rating) in establishing an office located in South Tangerang area by using the location of the place efficiently and effectively, (Pan and David, K2000). The workshop layout used by Bunnies is Functonal Layout, ie layout where similar resources or processes are collected in one location or located in adjacent locations. The layout of each facility at the workshop uses Activity Relationship Chart (ARC) to indicate whether or not the relevance between each facility is planned and the reasons for its relevance are several factors to consider including: (i) efficiency of the room; (ii) activity efficiency includes space and time between personnel and machines; (iii) security. To establish the goals and objectives of the operation strategy, PT. Bunnies Cinta Kasih employs several strategies to ensure consistency between the quality of caregivers and educators generated with market requirements in order to establish the appropriate parameters to be the goals and objectives of the company.

The company must be able to meet all customer needs both in terms of quality and in terms of caregivers and educators who are in daycare and after-school programs in Bunnies. It is not impossible in the future that there will be a demand for a new product type, therefore Bunnies should be able to look at all the dynamics of other daycare growth, especially daycare by continuing to process improvement and development both in terms of curriculum and existing programs. Hence, it can determine the priority in the purpose of operation needs to be grouping factors that affect the competitive advantage. Daycare and After School Program of Bunnies have a goal in managing human resources within the company either directly or indirectly involving in the operation of the company. The goals and objectives of the company are divided into three which are short, medium and long term. Operational objectives in the decisions that are generated to meet these objectives include decision support facilities that are decisions related to human resources, planning, control and improvement of the operating system. Besides, the main decision means that it is related to the decision of the model formed for input operation, processes and product output ie supply network design, process technology design and final product innovation in the operational process. Similarly, the process of mapping and identification is used in the planning stage of the process flow of implementation on Bunnies daycare and after school program. It aims to know the various activities that occur during the process of running care and daycare programs in daycare and after school programs.

In running Bunnies company, in addition to producing quality children as well as the lovely conduct like home, Bunnies will also develop different daycare and after school programs from elsewhere. The development of daycare education programs and after-school programs is done to be more acceptable to the market in terms of job development process and the use of appropriate childcare and nursery services in terms of quality and technology. The rules of Bunnies daycare and after school programs that apply are guidelines for workers from high to bottom levels as daily operational operators in the running of the company. Curriculum in PT. Bunnies Cinta Kasih is using Brain Challenging to develop an integrated curriculum that includes language, cognitive, music, and physical activity, creative, social-emotional, and moral education using computerization. In its education program, Bunnies pays attention on four things related to child development, namely motor, social, analytical, and linguistic. In Bunnies, children will not only be taught academic material in the form of mathematical calculations, but will also a number of educational games will be played.

Marketing Strategy. After School and Daycare program of Bunnies use process segmentation of upper and upper middle class with age group 25-45 years old who already work and have their own income, which we can see in table below spread in South Tangerang City. On business targeting, after school and daycare program target parents aged $25-45$ years who can be handled in a year with 656,498 people. In promoting Bunnies 
company, it uses Integrated Marketing Communication methods consisting of word of mouth, direct marketing, event, advertising, and public relations (Armstrong et al., 2015). Promotion with word of mouth is done by using online method through internet media and social media like delivery via Whatsapp messenger, Blackberry messenger, Facebook, Twitter, Line, and Instagram. In direct marketing method, after school and daycare program of Bunnies is to cooperate with the school community and residential housing in Gading Serpong to build a stand in the school and housing complex partners who aim to provide information about the activities of after school and daycare program of Bunnies to prospective customers.

After school and daycare program of Bunnies also utilize the Tools event, for the sixth month after the opening with holding seminars or counseling with several topics such as education and child health. In terms of advertising, after school and daycare program of Bunnies utilize online advertising. Online advertising method of after school and daycare program of Bunnies will be available on website www.bunnies.com and applications known by the community such as Instagram, Facebook, Line, and Google My Business. On these website and apps, it contains company profile, ways to register or enroll, news info about education and child health, contact and career.

Public relation is the last tool that is used in promotional activities of after school and daycare program of Bunnies. In this activity, this public relation will conduct an opening or open house event that invites some mass media either newspaper media or television media such as online press from government of South Tangerang website and the bloggers who already have good reputation with the number of followers above ten thousands.

After school and daycare program of Bunnies that will be established uses a system based on Customer Relationship Management with its application include front office and back office. Starting from the front office that deals directly with the customer up to the back office, it uses a system connected in online streaming. Customer Relationship Management used in after school and daycare program of Bunnies is an online system where when parents of prospective learners need parenting and education for their children, they can order easily among them with a procedure that must be completed first such as student data, history of disease, and an overview of the condition of the learner. Parents of the learner can order through conventional or online booking served by the front office or administrative part of the after school and daycare program of Bunnies until learners get these services well and optimally.

\section{CONCLUSION}

After school and daycare program of Bunnies, which is a child education institution, is trying to perfect the same educational institution by improving the service and human resources professional in its field. With the presence of Bunnies, it is expected to be a solution for parents who have difficulty caring for their children when working so they can work quietly and can dig intellectual, talent, and intelligence of children in an optimal and directed way. After school and daycare program of Bunnies, as a business plan discussed in this paper, is a business opportunity that has a profitable business prospects. Given the demand for daycare services and after-school programs that have not been well served, Bunnies is present in the midst of the needs of parents of children who need daycare services and after-school programs. It is also supported by caregivers and educators who have good quality and expert in their field.

\section{REFERENCES}

1. Armstrong, G., Kotler, P., Harker, M., \& Brennan, R. (2015). Marketing: an introduction. Pearson Education.

2. Brahmasari, I. A., \& Siregar, P. (2009). Pengaruh Budaya Organisasi, Kepemimpinan Situasional dan Pola Komunikasi terhadap Disiplin Kerja dan Kinerja Karyawan pada PT. Central Proteinaprima Tbk. Jurnal Aplikasi Manajemen, 7(1), 238-250. 
3. DuFour, R. (2004). Leading edge: The best staff development is in the workplace, not in a workshop. Journal of Staff Development, 25(2), 63-64.

4. Geoffroy, M. C., Côté, S. M., Parent, S., \& Séguin, J. R. (2006). Daycare attendance, stress, and mental health. The Canadian Journal of Psychiatry, 51(9), 607-615.

5. Grundy, T. (2006). Rethinking and reinventing Michael Porter's five forces model. Strategic Change, 15(5), 213-229.

6. Hersey, P., Blanchard, K. H., \& Johnson, D. E. (2007). Management of organizational behavior (Vol. 9). Upper Saddle River, NJ: Prentice hall.

7. Mahoney, J. L., Lord, H., \& Carryl, E. (2005). An ecological analysis of after-school program participation and the development of academic performance and motivational attributes for disadvantaged children. Child development, 76(4), 811-825.

8. Pan, Y., \& David, K. T. (2000). The hierarchical model of market entry modes. Journal of international business studies, 31(4), 535-554.

9. Porter, M. E. (2008). The five competitive forces that shape strategy. Harvard business review, 86(1), 25-40.

10. Rustandi, R. A. (2007). Gaya Kepemimpinan (Pendekatan Bakat Situasional). Bandung, Amrico.

11. Schermerhorn, J. R., Hunt, J. G., \& Osborn, R. N. (2000). Organizational behavior. John Wiley \& Sons Inc., New York.

12. Smith, J., \& Brown, T. (2012). APs in 'hospice at home'and daycare in the northwest. British Journal of Healthcare Assistants, 6(11), 560-565. 